\title{
Talent Retention in Private Universities of Malaysia
}

\author{
Suguna Sinniah, Ramesh Kumar Moona Haji Mohamed, Wan Rozima Mior, Ahmad Harith, \\ Wan Nur Izni, Zainab Ali Rawshdeh
}

\begin{abstract}
Enhancements in human capital can be achieved by the establishment of various programs such as training and curriculum development at the university level. This would increase the knowledge and skills of lecturers with respect to their teaching styles and learning processes at universities in general. This study examines the effect of human resources management (HRM) and job satisfaction on university PhD holders who contribute to the innovative achievements of a university. The purpose of this study was to explore the contribution of HRM and job satisfaction on talent retention in private universities in Malaysia. The study sample comprised 110 PhD holders, and their responses were analyzed using the PLS-SEM software. The results indicate that, rather than promotions and recognition, PhD holders place more emphasis on their salaries, which are very low at private universities. The study limitations are discussed, and suggestions are made regarding future research
\end{abstract}

Keywords: Recognition, Talent retention, Work Environment, Job Satisfaction.

\section{INTRODUCTION}

Currently in Malaysia, educational problems at the university level are related to the need to improve the levels of achievement of university lecturers. Thus, the Malaysian Ministry of Higher Education has set as its 2023 target that the country will have $60,000 \mathrm{PhD}$ holders, i.e., Doctor of Philosophy. In 2016, a total of 1,967 Malaysians obtained their PhD degrees. This figure represents just $0.006 \%$ of the country's population. On average, $16.9 \%$ of Malaysians obtain their PhDs each year. Between 2005 and 2016, Malaysia had 17,149 $\mathrm{PhD}$ degree holders (1). In this revolutionary 4.0 technology era, increasing the number of $\mathrm{PhDs}$ is a smart move toward increasing the knowledge base of the labour force in the education industry. Various efforts have been undertaken by universities to improve the quality of university education in the pursuit of university excellence, such as the development of a tailored curriculum designed and implemented by lecturers directly involved with their students in teaching and learning processes (2). In addition,

Revised Manuscript Received on September 22, 2019.

* Correspondence Author

Suguna Sinniah*, Faculty of Business and Accountancy, SEGi University, Malaysia,: Suguna@segi.edu.my

Dr. Ramesh Kumar Moona Haji Mohamed, Faculty of Business \& Finance, University Tunku Abdul Rahman (UTAR) Malaysia

Ms Wan Rozima Binti Mior Ahmed Shahimi, Faculty of Business \& Finance, University Tunku Abdul Rahman (UTAR) Malaysia

Mr. Ahmad Harith Ashrofie bin Hanafi, Faculty of Business \& Finance, University Tunku Abdul Rahman (UTAR) Malaysia.

Ms. Wan Nur Izni binti Wan Ahmad Kamar, Faculty of Business \& Finance, University Tunku Abdul Rahman (UTAR) Malaysia.

Ms.Zainab Ali Ahmad Rawshdeh, University Kebangasaan Malaysia (UKM)

enhancements in the job satisfaction of lecturers, career development, and management quality at universities can also be achieved through training, adequate salaries, bonuses, awards, seminars, teaching activities, research, fieldwork, and disciplinary teaching and learning facilities at universities in Malaysia and abroad $(3,4)$. According to $(5)$ job satisfaction tends to affect the performance of employees, i.e., an organisation that has employees who express a high degree of job satisfaction tend to experience talent retention.

However, currently, PhD lecturers in Malaysia face problems that may be affecting their job satisfaction (6)which can result in reduced productivity, absenteeism, inability to meet student needs and other problems (7). According to the Pollian Educational Poll, $51.7 \%$ of academic staff at universities and colleges intends to seek new jobs rather than remain at higher education institutions. When staff feels this way, it can only have a negative effect on the turnover rate of the higher education industry. High turnover rates also lead to a reduction in the number of students who feel confident in their universities or colleges (8).

Prior study showed that, many organisations in Malaysia lack compensation systems that can meet the needs of their academic staff, as well as having a poor work environment, lack of recognition and other factors (9). Several factors influence job satisfaction, including salary, promotion, work environment and recognition. According to 'The poor working environment has lowered the teaching profession.' If academic staff does not have adequate support to carry out their work, they may not put forth their best teaching effort. Based on a 2010 report by the National Economic Advisory Council, Malaysia's rate of skilled migration to Singapore continues to increase, due to Singapore's better working environment, higher wages and higher promotion opportunities, to name a few (11). The work environment is an important factor that helps to maintain staffing levels and improve job satisfaction.

Based on the average overall salary of the academic staff of the Commonwealth Universities Association, Malaysia's academic salary is lowest when compared to those of Singapore, Hong Kong, South Africa, Canada, Australia, the United Kingdom and New Zealand (12). In other words, there is a high likelihood that academic staff in Malaysia cannot meet their salary expectations. When employees receive lower wages, they have low job satisfaction, whereas when they receive higher salaries, they experience a high degree of job satisfaction (13). The salary package offered by the National University of Singapore is much higher than that offered by the University of Malaya (UM) (14). The results of this research can benefit the education industries' departments with respect to the problems they face. 


\section{LITERATURE REVIEW}

This study is based on the motivational theory known as equity theory, which was introduced in 1963 by John Stacey Adams, a psychologist specializing in work and behaviour, who successfully developed this motivational theory of work (15). The equity theory concerns the balance between input and output. According to this theory, input is a contribution made in an assignment or job whereas output is a reward or return for what was received from the input. Input typically involves effort, loyalty, hard work, commitment, skill, ability, flexibility, tolerance, determination, support from colleagues and personal sacrifices. Output generally covers all of the financial rewards, facilities, retirement arrangements, bonuses, and even praise (11). Equity theory also acknowledges that subtle factors and variables can affect the assessments between employees and employers. For example, if an employer wants to motivate his worker, he can use this theory by balancing the input with the output. If an employee is working diligently, then the salary is well spent. With the offer of a high salary as output, then the input of the worker can also be expected to increase. The equity structure of work is based on input ratios to get desired results (12). When inputs increase based on the output offered, an individual will be motivated. So, based on equity theory, if one is satisfied with what he has contributed and earns returns that are worthy of his contribution, then there is a balance between input and output. However, if circumstances are such that a person feels he is not receiving the output he deserves based on what he has contributed, he may perceive an injustice.

\section{HYPOTHESIS DEVELOPMENT}

\section{A. Salary}

Various studies have found there to be a negative effect on job satisfaction if employees receive low salaries, whereas there is a positive effect on job satisfaction if employees receive high salaries (13). The job satisfaction level related to salary will directly influence employee performance, job involvement, motivation and job satisfaction (14). In other words, a company must fulfil its employees' pay satisfaction levels to realize an increase in its employees' job satisfaction levels. According to (15), there is a positive relationship between salary and job satisfaction that can be observed in every sphere of work. Based on the experiment conducted by (16), successful levels of pay satisfaction can increase the success of an organisation. This is because salary is a key factor motivating employees to do their best to contribute to the organisation. In other words, satisfied employees will work more efficiently and effectively.

\section{satisfaction}

$\mathrm{H}_{1}$ : Salary will positively affect employee

\section{B. Work Environment and Job Satisfaction}

Our review of many studies revealed a striking relationship between work environment and job satisfaction. Work environment is a key variable that influences the job satisfaction of employees. According to (17), most employees believe that personal comfort facilitates good job performance, especially personal safety and comfort and peaceful physical surroundings. (18) also proved the strong relationship between work environment and job satisfaction in their study. These authors found that if employees perceived low levels of constraints in their work environment, they tend to be satisfied. The effect of the employee work environment on job satisfaction is evident in a number of behavioural aspects. Comparing individual and organisational characteristics, the work environment is easier to influence (19). (20) reported that employees will influence their work environment and the work environment will influence employees, i.e., these elements interact.

\section{$\mathrm{H}_{2}$ : Work environment will positively affect employee satisfaction}

\section{Recognition and Job satisfaction}

Recognition is acknowledged by most experts as a crucial factor in job satisfaction, as rewards, including monetary and compensative benefits, are not the only employee motivators. Recognition gives an employee a certain status in an organisation and is a very important factor in employee job satisfaction. (21) reported that even though many factors contribute to job satisfaction, recognition is one of the important and contributes significantly. Although (22) reported that recognition contributes only a small degree toward job satisfaction, but nevertheless has a significant relationship with job satisfaction while an employee is working in an organisation. In addition, most employee commitment to an organisation is based on rewards and recognition. Different kinds of satisfaction lead to a variety of objectives and behaviours that arise from different motivations for different types of recognition (23). As a result, it is important to provide recognition programs for employees and most organisations fully comply with this approach (24). Therefore, recognition is an element that can become a major factor affecting employee satisfaction in an organisation.

\section{satisfaction.}

$\mathrm{H}_{3}$ : Recognition will positively affect employee

\section{Promotion and Job Satisfaction}

(25) reported that promotion has significant relevance to job satisfaction. (26) alo stated that workers who are given the opportunity for promotion will be more loyal to their firms, and this may positively affect their performance and lower their intention to leave the firm. Moreover, (27) also found promotion to influence job satisfaction. Using the correlation coefficient method (28), found that promotion has a considerable relationship with job satisfaction and reported that an employee would be more satisfied with their job if they were given a promotional opportunity. This statement is supported by (29), who found sufficient evidence to prove that promotion can increase job satisfaction. (3) stated that if a worker is not promoted, he/she cannot meet his/her personal demands, which will affect how they adapt to their work environment. Therefore, lack of promotion will directly reduce his/her job satisfaction.

\section{$\mathrm{H}_{4}$ : Promotion will positively affect employee satisfaction.}

\section{E. Job Satisfaction and talent retention}

Studies have shown the negative impact of low job satisfaction on employee turnover (30). Highly satisfied employees react positively toward their organisation and this favourable reaction includes lower turnover rates and 
improved employee retention (31). A survey of public elementary schoolteachers in the state of Missouri, US, showed that satisfied teachers were more likely to stay in their jobs (32). At the same time, a positive significant relationship was found between employee job satisfaction at Lagos State University and employee turnover intention (29) . Moreover, the turnover intention among nurses was found to be significantly and negatively related to job satisfaction (33). In addition, job satisfaction was found to fully mediate the relationship between transformational leadership and turnover intention (34). Therefore, job satisfaction can be considered to be a major factor affecting talent retention in an organisation.

\section{$\mathrm{H}_{5}:$ Job Satisfaction will positively affect talent retention.}

\section{METHODOLOGY}

The sampling frame of this study comprised $\mathrm{PhD}$ holders at private universities in Malaysia. The research tool was a questionnaire with a pre-formulated set of written questions to which the respondents recorded their answers among a range of closely defined alternatives.

The questionnaire had four sections, with a total of forty-four questions. In Section A, the respondents provided profile and demographic information such as their gender, age, ethnicity and marital status. Section B addressed the HRM practices at their university, including salary, promotion, and recognition and working environment, measured by 20 questions adapted from the paper by (35) and modified for the current research context. In Section $\mathrm{C}$, the respondents answered eight questions regarding their job satisfaction, which were taken from the Minnesota Satisfaction Questionnaire. Section D comprised five questions about talent retention as developed by (36), which been modified for this research context.

The measurement of the study constructs, including salary, promotion, recognition, and working environment, were measured on a five-point Likert scale from $1=$ strongly disagree to $5=$ strongly agree. This scale was initially validated based on respondents' self-reported measures of intention to purchase and perception of factors related to products being tested. This scale is highly reliable and has high validity. This study used non-probability sampling, did the exact population of Ph.D. holders at the private universities are unknown. 300 sets of questionnaires were distributed to $\mathrm{PhD}$ holders, using a purposive convenience sampling technique, since the targeted $\mathrm{PhD}$ holders only to study talent retention at universities. The response rate was $48 \%$, with 145 completed questionnaires received, only 110 of which were usable for the analysis due to missing data and outliers (37). The 110-sample size was sufficient for our model, as determined using $\mathrm{G}$ power analysis software.

\section{RESULTS AND FINDINGS}

\section{A. Measurement model}

Prior to testing the model hypotheses, tested the reliability, validity of convergence and discrimination validity of all of the constructs' measurement models, the scores of which are shown in Table 3. As can see in the table, all the loads are higher than the 0.70 threshold proposed by (38). The composite reliability (CR) scores are > 0.7 (Hair et al., 2013), whereas the average variance extracted (AVE) for all the constructs is $>0.5$ (39). Based on these results, can conclude that convergent validity was attained. To examine any possibility of multicollinearity, tested the variance of inflation factor (VIF), and Table 3 shows that the VIF values are less than 3.3 for all the constructs, which is significantly less than the (40) threshold of 9. Thus, with no sign of multicollinearity, adequate construct validity is affirmed.

All constructs meet the proposition of (41) and (42) that ensure the validity of discrimination between constructs, the AVEs of every development must be more highly correlated with each other than with any other construct in the model. Based on (43), the validity of this discrimination is sufficient when all the measured variable load of items is at least 0.1 greater than their cross load.

In addition, this study tested discriminant validity using the (44) method - a Monte Carlo simulation-to verify the outstanding performance of this method, the results of which are shown in Table II. determined the heterotrait-monotrait ratio of correlations (HTMT) to assess the discriminant validity either as a criterion or as a statistical test. In the criterion case, there is a discriminant validity problem when the HTMT value is higher than 0.85 (45) or 0.90 (46). To determine measurement model fitness, the current study followed the steps reported by (47). Examined the saturated model and Standardized Root Mean Square Residual (SRMR) at a $95 \%$ bootstrap quantile. The SRMR is the only approximate model fit criterion applied in PLS path modelling (48). In addition, to contribute to the model fitness index in PLS and quantify the discrepancy between the two matrices, determined the geodesic discrepancy $(\mathrm{dG})$ and the unweighted least squares discrepancy (dULS) (44), which measure distances that relate more than one way. As shown in Table 4, the dG value is 0.97 and that of dULS is 1.521 , which indicate that the measurement model is well fitted (56). Moreover, the SRMR is 0.063 , which is less than the cut-off value of 0.08 (44), thus verifying the good fit of the measurement model in this study. 
Talent Retention in Private Universities of Malaysia

Table- I: Convergent validity

\begin{tabular}{|c|c|c|c|c|c|c|c|}
\hline Construct & Items & Loadings & Cronbach's Alpha & rho_A & $\mathbf{C R}$ & AVE & VIF \\
\hline \multirow[t]{2}{*}{ JSE } & JSE5 & 0.896 & 0.742 & 0.743 & 0.886 & 0.795 & 1.534 \\
\hline & JSE6 & 0.887 & & & & & 1.534 \\
\hline JSI & JSI1 & 1 & 1 & 1 & 1 & 1 & 1 \\
\hline \multirow[t]{6}{*}{$\mathbf{P}$} & P1 & 0.857 & 0.91 & 0.912 & 0.93 & 0.69 & 2.862 \\
\hline & P2 & 0.874 & & & & & 3.147 \\
\hline & P3 & 0.843 & & & & & 2.366 \\
\hline & P4 & 0.817 & & & & & 2.294 \\
\hline & P5 & 0.819 & & & & & 2.215 \\
\hline & P6 & 0.769 & & & & & 1.877 \\
\hline \multirow[t]{5}{*}{ RE } & RE2 & 0.801 & 0.859 & 0.86 & 0.899 & 0.64 & 2.242 \\
\hline & RE3 & 0.802 & & & & & 1.905 \\
\hline & RE4 & 0.834 & & & & & 2.401 \\
\hline & RE5 & 0.769 & & & & & 1.85 \\
\hline & RE6 & 0.79 & & & & & 1.925 \\
\hline \multirow[t]{5}{*}{ Salary } & $\mathrm{S} 1$ & 0.837 & 0.877 & 0.881 & 0.911 & 0.672 & 2.247 \\
\hline & $\mathrm{S} 2$ & 0.895 & & & & & 2.997 \\
\hline & S4 & 0.793 & & & & & 1.939 \\
\hline & S5 & 0.82 & & & & & 2.187 \\
\hline & S6 & 0.747 & & & & & 1.636 \\
\hline \multirow[t]{6}{*}{ TR } & TR1 & 0.786 & 0.884 & 0.89 & 0.912 & 0.632 & 2.06 \\
\hline & TR2 & 0.799 & & & & & 2.108 \\
\hline & TR3 & 0.828 & & & & & 2.285 \\
\hline & TR4 & 0.818 & & & & & 2.224 \\
\hline & TR5 & 0.811 & & & & & 2.528 \\
\hline & TR6 & 0.725 & & & & & 2.029 \\
\hline \multirow[t]{2}{*}{ WE } & WE4 & 0.913 & 0.761 & 0.771 & 0.893 & 0.807 & 1.607 \\
\hline & WE5 & 0.883 & & & & & 1.607 \\
\hline
\end{tabular}

Table -II HTMT

\begin{tabular}{lllllllll}
\hline & JSE & JSI & P & RE & Salary & TR & WE & \\
\hline JSE & & & & & & & SRMR & 0.063 \\
JSI & 0.804 & & & & & & d_ULS & 1.512 \\
P & 0.655 & 0.582 & & & & & d_G & 0.97 \\
RE & 0.721 & 0.385 & 0.634 & & & & Chi-Square & 584.214 \\
Salary & 0.852 & 0.614 & 0.691 & 0.706 & & & & \\
TR & 0.691 & 0.513 & 0.628 & 0.573 & 0.685 & & & \\
WE & 0.087 & 0.133 & 0.104 & 0.33 & 0.131 & 0.24 & & \\
\hline
\end{tabular}

Table -III HYPOTHESES RESULTS

\begin{tabular}{|c|c|c|c|c|c|c|c|}
\hline Hypothesis & Beta Value & Std Err & T-Value & P Values & $\mathbf{L L}$ & UL & Decision \\
\hline $\mathrm{H}_{1} \mathrm{RE}->\mathrm{JS}$ & 0.076 & 0.098 & 0.09 & 0.844 & 0.399 & 0.25 & Not Supported \\
\hline $\mathrm{H}_{2}$ Salary -> JS & 0.49 & 0.094 & 0.091 & 5.388 & 0 & 0.656 & Supported \\
\hline $\mathrm{H}_{3} \mathrm{WE}->$ JS & -0.002 & 0.07 & 0.066 & 0.027 & 0.979 & 0.147 & Not Supported \\
\hline $\mathrm{H}_{4}$ Promotion -> JS & 0.251 & 0.077 & 0.078 & 3.217 & 0.001 & 0.41 & Supported \\
\hline $\mathrm{H}_{5} \mathrm{JS}$-> TR & 0.577 & 0.083 & 0.086 & 6.682 & 0 & 0.725 & Supported \\
\hline
\end{tabular}

Note: JS- Job Satisfaction, RE- Recognition, WE- Work environment, TR- Talent retention 


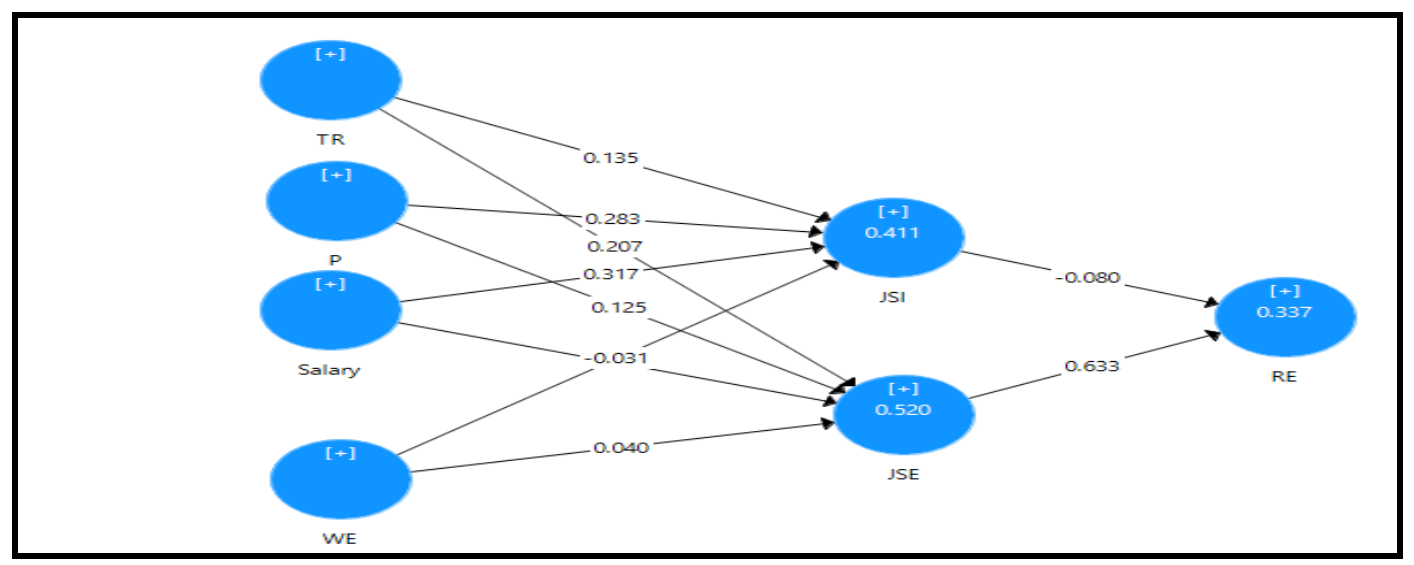

Figure I. Measurement Model

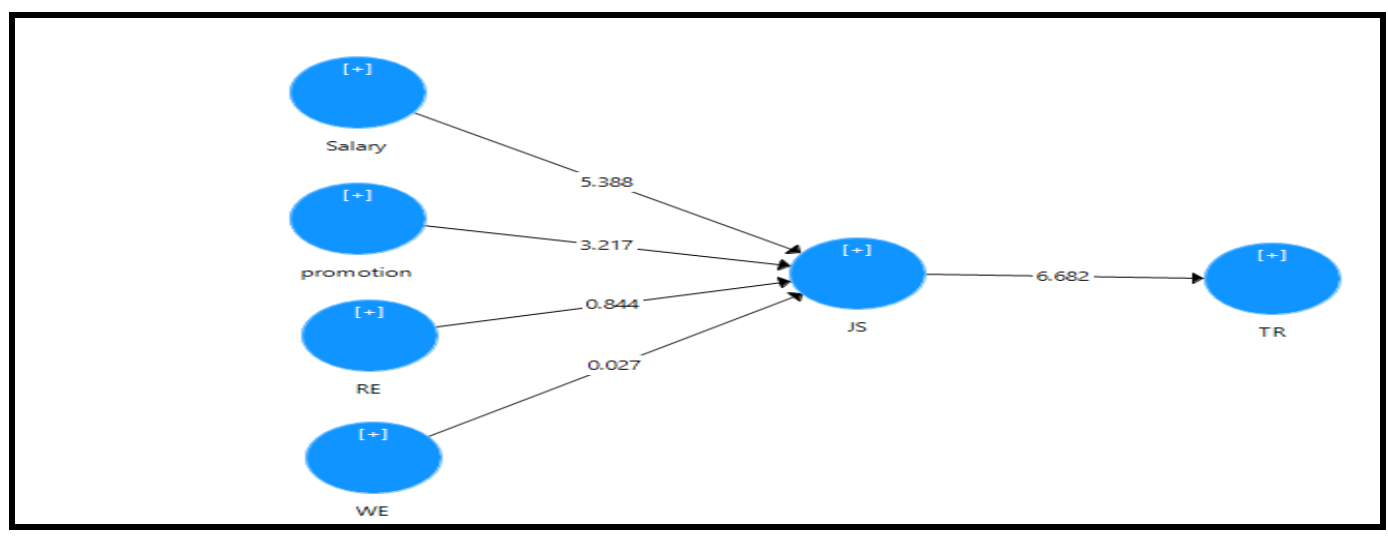

Figure II. Structural Model

\section{B. Structural model}

The study results are based on the input of 110 respondents, which were then analysed using Smart PLS 3.2.8 software. To ensure statistical significance of the path coefficients, the $\mathrm{t}$-statistics values at $\mathrm{p} \leq 0.1$ must have higher than a 1.65 confidence interval (43). In addition, an effect size of 0.35 denotes a large effect, 0.15 indicates a medium effect, and 0.02 a small effect (49). R2 is used to obtain the coefficient of determination for the dependent constructs. According to (50), 0.67 is a strong $\mathrm{R} 2$ value, 0.33 is moderate and 0.19 is weak. Similarly, (43)and (47) indicated that an R2 of 0.75 is strong, 0.5 is moderate and 0.25 is weak. However, (51) recommended that $\mathrm{R} 2$ be greater than or equal to 0.10 to sufficiently explain the variance of a particular endogenous construct. Accordingly, the $0.62 \mathrm{R} 2$ value of this study, as shown in Table III, is sufficient. A consistent PLS bootstrapping option starts by the use of 5000 subsamples to obtain the significance levels (43). Next, F2 test was performed to determine the power of this model. The purpose of determining the effect size (F2) is to help researchers to determine the best model. In Table 5, shows that the model has a fairly large effect size. As such, this study conclude that the model meets the inner model requirement. Table III shows the results for hypotheses $\mathrm{H} 1$ to $\mathrm{H} 5$, as well as their t-statistics. A hypothesis is significant when the t-value $>$ $1.645(\mathrm{p}<0.05)$, a t-value $>2.33(\mathrm{p}<0.01)$ for a 1 -tailed test, a t-value $>1.96(\mathrm{p}<0.05)$ or a t-value $>2.58(\mathrm{p}<0.01)$. Thus, from Table 5, displays that $\mathrm{H} 2, \mathrm{H} 4$, and $\mathrm{H} 5$ are significant, as both their lower and upper limits are positive, since a hypothesis becomes significant at zero. The remaining two hypotheses $\mathrm{H} 1$ and $\mathrm{H} 3$ are not supported.

\section{IIV. IMPLICATION AND DISCUSSION}

This research found that salary is the factor that have the greatest effect on employee job satisfaction. Thus, higher education providers in Malaysia should emphasise salary allocations to improve the quality and performance of employees in their organisations. In fact, our study results indicate that employees will demonstrate upward mobility if their salaries are fair and equitable. Proper salary allocations will result in high job quality and performance and generate positive impacts on the efficiency and effectiveness of an organisation. Most employees will compare their job conditions with those of their colleagues or those serving in similar positions to determine whether their salaries are reasonable and commensurate with their duties and responsibilities. To ensure employee retention and attract talent from other organisations, universities should evaluate the market value of salaries across the industry and offer higher compensation than others. In addition, an employee who is highly satisfied with his salary will also feel valued by the organisation.

In addition, this study found promotion to effectively predict job satisfaction in higher education institutions in Malaysia. Therefore, if an organisation promotes its employees within the hierarchy or even shifts those to a better rank with more responsibility in recognition of their efforts, employees will feel more satisfaction with their jobs. Promotion and salary are also interconnected, which is another way to effectively predict job 
satisfaction. As a factor with positive impact, promotion can significantly affect employee salaries and, thus, job satisfaction henceforward. Therefore, organisations should emphasise promotion and use it advisedly to ensure employee retention in this fiercely competitive industry and to successfully pursue productive employees. In conclusion, higher education institutions in Malaysia should put greater emphasis on employee job satisfaction to significantly and positively affect the performance of their organisations.

In conclusion, the results of our research may be used by universities currently offering low employee compensation packages to justify the offer of better employee compensation and, thereby, increase employee job satisfaction and enhance university performance and talent retention rates. In addition, based on our study results, managers are encouraged to understand the strength of their employees and assign them tasks that best fit their positions and talents without burdening them with irrelevant tasks not specific to their professional areas.

\section{REFERENCES}

1. The Star

2. Bajunid IA, Wong WCK. Private higher education institutions in Malaysia. In: A Global Perspective on Private Higher Education. 2016.

3. Sinniah S, Makhbul ZKM, Perumal G, Mohamed RKMH. Career motivation among lecturers' working at private universities in malaysia. Int J Bus Manag Sci. 2018;

4. Ros V, Oleksiyenko A. Policy Misalignments and Development Challenges in the Cambodian Academic Profession: Insights from Public University Lecturers. High Educ Policy. 2018;

5. Carmeli A, Brammer S, Gomes E, Tarba SY. An organizational ethic of care and employee involvement in sustainability-related behaviors: A social identity perspective. J Organ Behav. 2017;

6. Anis A, Islam R, Abdullah NA. Challenges faced by Malaysian private HLIs in providing quality education: a thematic analysis. Qual Assur Educ. 2018;

7. Richardson C, Wong HW. Expatriate academics in Malaysia: motivation, adjustment, and retention. J Manag Dev. 2018;

8. Zahid Noor. Impact of Job Promotion and Job Advancement on Job Satisfaction in Universities of KPK Province of Pakistan. Sci Int. 2015;

9. Tyson AD, Jeram D, Sivapragasam V, Azlan HN. Ethnicity, education and the economics of brain drain in Malaysia: Youth perspectives. Malaysian J Econ Stud. 2011;

10. Parnes HS, Granovetter MS. Getting a Job: A Study of Contacts and Careers. Ind Labor Relations Rev. 1976;

11. Martelli PF, Stimmler MK, Roberts KH. Organizational Behavior. In: Encyclopedia of Human Behavior: Second Edition. 2012.

12. Virtanen M, Elovainio M. Justice at the Workplace: A Review. Cambridge Q Healthc Ethics. 2018;

13. Basak SK, Govender DW. Theoretical Framework Of The Factors Affecting University Academics Job Satisfaction. Int Bus Econ Res J. 2015;

14. Masum AKM, Azad MAK, Beh LS. Determinants of academics' job satisfaction: Empirical evidence from private universities in bangladesh. PLoS One. 2015;

15. Salisu JB, Chinyio E, Suresh S. The impact of compensation on the job satisfaction of public sector construction workers of jigawa state of Nigeria. The Business and Management Review. 2015.

16. Braun S, Peus C, Weisweiler S, Frey D. Transformational leadership, job satisfaction, and team performance: A multilevel mediation model of trust. Leadersh Q. 2013;

17. Hayes B, Douglas C, Bonner A. Work environment, job satisfaction, stress and burnout among haemodialysis nurses. J Nurs Manag. 2015;

18. AbuAlRub R, El-Jardali F, Jamal D, Abu Al-Rub N. Exploring the relationship between work environment, job satisfaction, and intent to stay of Jordanian nurses in underserved areas. Appl Nurs Res. 2016;

19. Rowley J. Motivation and academic staff in higher education. Qual Assur Educ. 1996;4(3):11-6.

20. Raziq A, Maulabakhsh R. Impact of Working Environment on Job Satisfaction. Procedia Econ Financ. 2015;

21. Wang F, Pollock K, Hauseman C. School Principals' Job Satisfaction: The Effects of Work Intensification. Can J Educ Adm Policy. 2018;

22. Bechtoldt MN, Beersma B, van Kleef GA. When (not) to empathize: The differential effects of combined emotion recognition and empathic concern on client satisfaction across professions. Motiv Emot. 2019;

23. Lee KC, El-Ibiary SY, Suchanek Hudmon K. Evaluation of research training and productivity among junior pharmacy practice faculty in the United States. J Pharm Pract. 2010;

24. Jessen JT. Job satisfaction and social rewards in the social services. J Comp Soc Work. 2010;

25. Porter LW, Steers RM, Mowday RT, Boulian P V. Organizational commitment, job satisfaction, and turnover among psychiatric technicians. J Appl Psychol. 1974;

26. Alam SMT. Factors Affecting Job Satisfaction, Motivation and Turnover Rate of Medical Promotion Officer (MPO) in Pharmaceutical Industry: A Study Based in Khulna City. Asian Bus Rev. 2015;

27. Khamisa N, Oldenburg B, Peltzer K, Ilic D. Work related stress, burnout, job satisfaction and general health of nurses. Int J Environ Res Public Health. 2015;

28. Pan B, Shen X, Liu L, Yang Y, Wang L. Factors associated with job satisfaction among university teachers in northeastern region of China: A cross-sectional study. Int J Environ Res Public Health. 2015;

29. Lai M, Chen Y. Self-efficacy, effort, job performance, job satisfaction, and turnover intention: The effect of personal characteristics on organization performance. Int J Innov Manag Technol. 2012;

30. Tian-Foreman W. Job satisfaction and turnover in the Chinese retail industry. Chinese Manag Stud. 2009;

31. Ainer CD, Subramaniam C, Arokiasamy L. Determinants of Turnover Intention in the Private Universities in Malaysia: A Conceptual Paper. SHS Web Conf. 2018;

32. Perrachione BA, Rosser VJ, Petersen GJ. Why Do They Stay? Elementary Teachers' Perceptions of Job Satisfaction and Retention. Prof Educ. 2008;

33. Cai Liu N, Cheng Y. Global university rankings and their impact. In: Leadership for World-Class Universities: Challenges for Developing Countries. 2011

34. Jia A, Lim P, Teck J, Loo K, Lee PH. The Impact of Leadership on Turnover Intention: The Mediating Role of Organisational Commitment and Job Satisfaction. J Appl Struct Equ Model. 2017;

35. Al-Nsour M. Relationship between Incentives and Organizational Performance for Employees in the Jordanian Universities. Int J Bus Manag. 2011;

36. Kyndt E, Dochy F, Michielsen M, Moeyaert B. Employee retention Organisational and personal perspectives. Vocat Learn. 2009;

37. Sekaran U. Research Methods for Business Research Methods for Business. Research methods for business. 2012.

38. Hair JF, Anderson RE, Tatham RL, Black WC. Multivariate Data Analysis (7th Edition). Uppersaddle River, New Jersey: Pearson Education International. 2010.

39. Bagozzi RP. Evaluating Structural Equation Models with Unobservable Variables and Measurement Error: A Comment. J Mark Res. 2006;

40. Yong AG, Pearce S. A Beginner's Guide to Factor Analysis: Focusing on Exploratory Factor Analysis. Tutor Quant Methods Psychol. 2013;

41. Fornell C, Larcker DF. Evaluating Structural Equation Models with Unobservable Variables and Measurement Error. J Mark Res. 1981;

42. Anderson JC, Gerbing DW. Assumptions and Comparative Strengths of the Two-Step Approach:Comment on Fornell and Yi. Sociol Methods Res. 1992;20(3):321-33.

43. Hair JF, Ringle CM, Sarstedt M. PLS-SEM: Indeed a silver bullet. J Mark Theory Pract. 2011;

44. Dijkstra TK, Henseler J. Consistent and asymptotically normal PLS estimators for linear structural equations. Comput Stat Data Anal. 2015;

45. Kline S, McClintock F. Describing uncertainties in single-sample experiments. Mech Eng. 1953;

46. Gold AH, Malhotra A, Segars AH. Knowledge management: An organizational capabilities perspective. J Manag Inf Syst. 2001;

47. Sarstedt M, Henseler J, Ringle CM. Multigroup analysis in partial least squares (PLS) path modeling: Alternative methods and empirical results. Adv Int Mark. 2011;

48. Henseler J, Ringle CM, Sarstedt M. Testing measurement invariance of composites using partial least squares. Int Mark Rev. 2016;

49. Lowry PB, Gaskin J. Partial least squares (PLS) structural equation modeling (SEM) for building and testing behavioral causal theory: When to choose it and how to use it. IEEE Trans Prof Commun. 2014; 
50. Chin WW. The Partial Least Square Approach to Structural Equation Modeling. In: Modern Methods for Business Research. 1998. p. 295-336.

51. Falk R, Miller NB. A Primer for Soft Modeling. Open J Bus Manag. 1992;

\section{AUTHORS PROFILE}

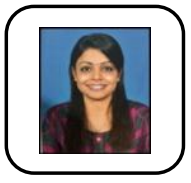

Ms. Suguna Sinniah is a Senior Lecturer at Faculty of Business, Accounting and Management, SEGi University, Kota Damansara. She has 12 years of experience in cooperate and academia. Her expertise is in the areas of human resource management, organizational behavior and international business. She has taught various subjects such as strategic management, organizational behavior, entrepreneurship, international business, business ethics and human resource management. She has published numerous papers in peer reviewed international journals as to date. Ms. Suguna holds a Master degree in Human Resource Management and Bachelor's degree in Business Administration. She is currently pursuing her $\mathrm{PhD}$ studies.

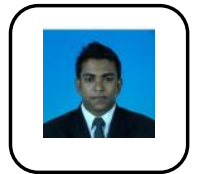

Dr. Ramesh Kumar Moona Haji Mohamed currently is an Assistant professor for the Faculty of Business \& Finance, University Tunku Abdul Rahman (UTAR) Malaysia. He received his Master's degree in MBA from the University of Utara Malaysia (UUM) Graduate with B.Mgmt, (Hons) Major in Management and Minor in Political Science from the Universiti Sains Malaysia. He pursued his Ph.D. from USM in Human Resource Management field. He has more than 12 years of progressive Human Resource Executives experience and 12 years of teaching experience.

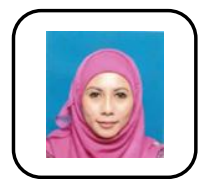

Ms Wan Rozima Binti Mior Ahmed Shahimi is a Finance's PhD Candidate, and also a Finance Lecturer at the Finance Department of Faculty of Finance and Business, Universiti Tunku Abdul Rahman (UTAR). She accomplished her Bachelor of Finance (Hons) from Universiti Utara Malaysia (UUM) and her Master of Risk and Technology in Risk Management from University of New South Wales (UNSW), Australia. She has been working as a lecturer for almost ten years with the specializations on Business Finance, Financial Management, Corporate Finance and International Finance. Her current research areas are Financial Management and Financial Planning. Besides, her interest areas are on Investment and Current Issues on the aspect of finance matters. Her work has published in various journals including International Journal of Science Arts and Commerce, International Journal of Accounting, Finance and Business, Journal of Global Business and Social Entrepreneurship and China-USA Business Review.

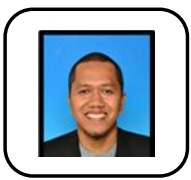

Mr. Ahmad Harith Ashrofie bin Hanafi is a Finance lecturer at the Banking and Finance Department of Faculty of Business and Finance, Universiti Tunku Abdul Rahman (UTAR) and also Universiti Utara Malaysia's (UUM) PhD candidate. He completed his Master of Science Finance in UUM and BBA (Hons) Finance in Universiti Teknologi MARA (UiTM). He work for UTAR for almost 5 years with specialization on bankruptcy, unit trust, investment and corporate finance. Currently, his research focus on Financial Distress area. His other interest area are on the any current issue related to asset pricing models, risk evaluation and investors behaviour. His work has published in banking and finance journal like International Journal of Accounting, Finance and Business.

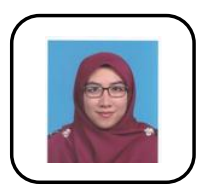

Ms. Wan Nur Izni binti Wan Ahmad Kamar currently is serving at Universiti Tunku Abdul Rahman (UTAR) Kampar as an Economics Lecturer. She has been working with UTAR for almost 5 years. She completed her Bachelor of Economic (Hons) (International Economics) from Universiti Malaysia Sarawak (UNIMAS) and her Master's of Science (Finance) from Universiti Utara Malaysia (UUM). Her areas of teaching are in Microeconomics and Macroeconomics. Besides that, her current research interest are on Microeconomics, Macroeconomics as well as Financial Economics and any general issues related to economics. Her work has been published in few reputable journals.

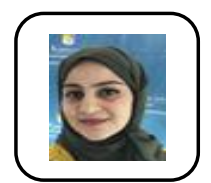

Ms.Zainab Ali Ahmad Rawshdeh a PhD scholar at Graduate School of Management, University Kebangsaan Malaysia. She has 3 years of teaching experience with Taibah University KSA. She obtained his Bachelor of Computer sciences from Yarmouk University Jordan, Master of Business Administration from Yarmouk University Jordan. Her research interest includes HRM, CSR 